\title{
Trophic Features, Benthic Recovery, and Dominance of the Invasive Mytilopsis Sallei in the Yundang Lagoon (Xiamen, China) Following Long-Term Restoration
}

\author{
Paolo Magni ${ }^{1, *(\mathbb{D}}$, Serena Como ${ }^{1}$, Maria Flavia Gravina ${ }^{2,3}$, Donghui Guo ${ }^{4}$, $\mathrm{Chao}^{\mathrm{Li}}{ }^{4}$ and \\ Lingfeng Huang ${ }^{5, *}$ \\ 1 National Research Council of Italy, Institute for the Study of Anthropogenic Impact and Sustainability in \\ Marine Environment (CNR-IAS), 09170 Oristano, Italy \\ 2 Dipartimento di Biologia, Università di Roma "Tor Vergata", 00133 Rome, Italy \\ 3 Consorzio Nazionale Interuniversitario per le Scienze del Mare (CoNISMa), Piazzale Flaminio 9, \\ 00196 Rome, Italy \\ 4 State Key Laboratory of Marine Environmental Science, College of Ocean and Earth Sciences, \\ Xiamen University, Xiamen 361102, Fujian, China \\ 5 Key Laboratory of the Ministry of Education for Coastal and Wetland Ecosystems, \\ College of the Environment and Ecology, Xiamen University, Xiamen 361102, Fujian, China \\ * Correspondence: paolo.magni@cnr.it (P.M.); huanglf@xmu.edu.cn (L.H.)
}

Received: 20 June 2019; Accepted: 12 August 2019; Published: 15 August 2019

\begin{abstract}
A comprehensive set of physicochemical variables in near-bottom water and surface sediments, as well as the soft-bottom macrozoobenthic assemblages were investigated at six sites across the Yundang Lagoon (Southeast China) in November 2012. This lagoon was severely damaged in the 1970s due to domestic and industrial pollution and land reclamation and underwent a massive restoration effort over the past 30 years. Our objectives were to: (1) assess the current trophic and environmental condition of the lagoon; (2) investigate the pattern of spatial variation in the macrozoobenthic assemblages; and (3) assess the benthic recovery in relation to the main environmental gradients and the presence of invasive alien species. Nutrient, chlorophyll- $a$, biological oxygen demand $\left(\mathrm{BOD}_{5}\right)$, chemical oxygen demand $\left(\mathrm{COD}_{\mathrm{Mn}}\right)$, and total organic carbon $(\mathrm{TOC})$ concentrations were lower than those reported in previous decades, yet organically-enriched conditions occurred at an inner site. From azoic conditions in the 1980s and a few benthic species reported prior to this study, we found a significant increase in benthic diversity with 43 species heterogeneously distributed across the lagoon. The invasive bivalve Mytilopsis sallei was the dominant species, which was associated with the richest benthic assemblage. However, $M$. sallei is a pest species, and its spatiotemporal distribution should be carefully monitored. These results highlight the central role of the macrozoobenthos in providing important ecological information on the current status of the Yundang Lagoon and as an effective biological tool to follow the recovery's progress and the future evolution of this highly valued ecosystem.
\end{abstract}

Keywords: macroinvertebrates; biodiversity; eutrophication; saprobity; organic pollution; spatial variation; sediments; coastal lagoons; invasive alien species

\section{Introduction}

Coastal lagoons are typically human-managed, highly productive ecosystems which provide multiple uses and services [1-3]. However, in the last few decades, engineering interventions have 
increasingly affected lagoons' morphology, hydrodynamics, and sedimentology, resulting in excessive inputs of nutrients and organic matter $(\mathrm{OM})$ that have led to eutrophication and organic over-enrichment of the sediments [4-7]. These factors have profoundly impaired the biological structure, trophic status, and functioning of coastal lagoon systems worldwide [8-11]. As an example, dystrophic events are the cause of anoxia, sulfide development, mass mortalities, and shifts to alternative ecohydrological states characterized by reducing conditions and lower $\mathrm{pH}$ [12-15]. Within this context, the concept of "saprobity", originally developed for rivers and lakes more than a century ago [16,17], applies well to coastal lagoons as a "state descriptor" of the ecosystem's condition resulting from the input and decomposition of OM and the removal of its catabolites [18]. Thus, both the trophic features (i.e., the amount of nutrients and OM in water and sediments) and the degree of saprobity (i.e., the balance between input of $\mathrm{OM}$ and other processes such as mineralization, sinking, dilution and export of $\mathrm{OM}$ ) are instrumental for assessing the natural conditions and the environmental quality of a lagoon. Contrary to estuaries where the salinity gradient is dominant [19], the seawater renewal and hydrodynamics strongly govern the land-sea gradient in coastal lagoons [18,20]. Several field studies have described how species or groups of benthic organisms reduce their abundance in a given order as environmental stress increases, and how the number of taxonomic groups is reduced as stress increases [21-25]. Similarly, the main effect of saprobity on the macrozoobenthic assemblages is that the number of species that can cope with it decrease progressively as saprobity increases, leading to a reduction of species richness and diversity $[18,26]$. Yet, OM input associated with low saprobity due to high oxygen availability or low by-product (e.g., ammonia and sulfide) concentrations can promote the vitality of the biocoenosis, increasing biomass and abundance.

In China, many coastal areas are experiencing major urban and economic development, which is often coupled with growing anthropogenic pressures such as land reclamation, which often causes loss of coastal wetlands and serious environmental problems [27]. Monitoring and assessment of man-made pollutants and their sources are, thus, crucial for evaluating the environmental quality of these areas, including coastal lagoons, located at the interface between continental and marine ecosystems. Accordingly, a substantial body of legislation exists to address environmental protection in China, such as laws on Water (21 January 1988) and Environmental Protection (26 December 1989), Sea Water Quality GB 3097-1997, Environmental Quality for Surface Water GB 3838-2002, and Provisions for Monitoring of Marine Culture and Propagation Areas (1 April 2002) [28]. The Yundang Lagoon is an urban water body located in the highly populated and industrialized city of Xiamen (Southeast China). This lagoon, a natural bay open to the sea and historically rich in marine species, was severely damaged in the 1970s due to domestic and industrial pollution and land reclamation for agriculture. In particular, the Yundang Lagoon was reduced in size by more than $90 \%$ (from $10 \mathrm{~km}^{2}$ before 1970 to $0.8 \mathrm{~km}^{2}$ by 1988) and suffered decreased water flow and enhanced siltation, anoxia, loss of habitat and species, and the eventual collapse of the whole ecosystem [29-31]. Thus, an integrated management program aimed at restoring the ecosystem was put in place in the late 1980s, which included clean-up activities, wastewater treatment, flood prevention, and sludge dredging. The lagoon was also opened to the outer bay of the Xiamen Sea through a diversion canal inlet in the early 1990s, coupled with new restoration actions including a mangrove plantation and phytoremediation techniques [29,32]. One of the main current aspirations of residents and the government is to restore the ecosystem services that a healthy Yundang Lagoon could provide [29,33].

Environmental and ecological studies in Chinese coastal lagoons are sparse, but growing steadily, owing to the scientific and socio-economic interest in these highly productive but fragile ecosystems [27,31]. Within this framework, in the present study the environmental and benthic features of the Yundang Lagoon were investigated as a unique case-study of a formerly "dead" lagoon which underwent a massive restoration effort over the past 30 years. We hypothesized that the long-term restoration interventions may have led to improved environmental and biological conditions of the lagoon. To address these issues, we analyzed a comprehensive set of physicochemical variables in water and sediments, as well as the macrozoobenthic assemblages, at six different sites across the Yundang Lagoon. Our objectives were 
to: (1) evaluate the trophic features of the lagoon and possible areas of major environmental concern; (2) investigate the pattern of spatial variation in the macrozoobenthic assemblages; and (3) assess the benthic recovery in relation to both the main environmental (e.g., trophic and saprobity) gradients and the presence of invasive alien species.

\section{Materials and Methods}

\subsection{Study Area}

The Yundang Lagoon was selected as the study site, a subtropical urban water body in Xiamen City, Southeast China, which connects to the Western Sea of Xiamen Island through a small canal controlled by a sluice (Figure 1). The Yundang Lagoon used to be a natural bay called Yundang Harbor. The harbor covered an area of about $10 \mathrm{~km}^{2}(6.3 \mathrm{~km}$ long and $1.6 \mathrm{~km}$ wide). A great number of land reclamation projects were carried out in the early 1970s, and the Yundang Harbor gradually became a dead lagoon unable to exchange water with the sea. The lagoon area was reduced from the original 10 $\mathrm{km}^{2}$ to only $2.2 \mathrm{~km}^{2}$ (1988 data, including $1.0 \mathrm{~km}^{2}$ of marshes). At present, the total water area of the Yundang Lagoon is approximately $1.5 \mathrm{~km}^{2}$, with a maximum depth of around $5 \mathrm{~m}$ and a drainage area of $37 \mathrm{~km}^{2}$, making up 30\% of Xiamen Island. The lagoon can be subdivided into different sectors, including a diversion canal, inner and outer sectors, and an innermost canal (Figure 1).

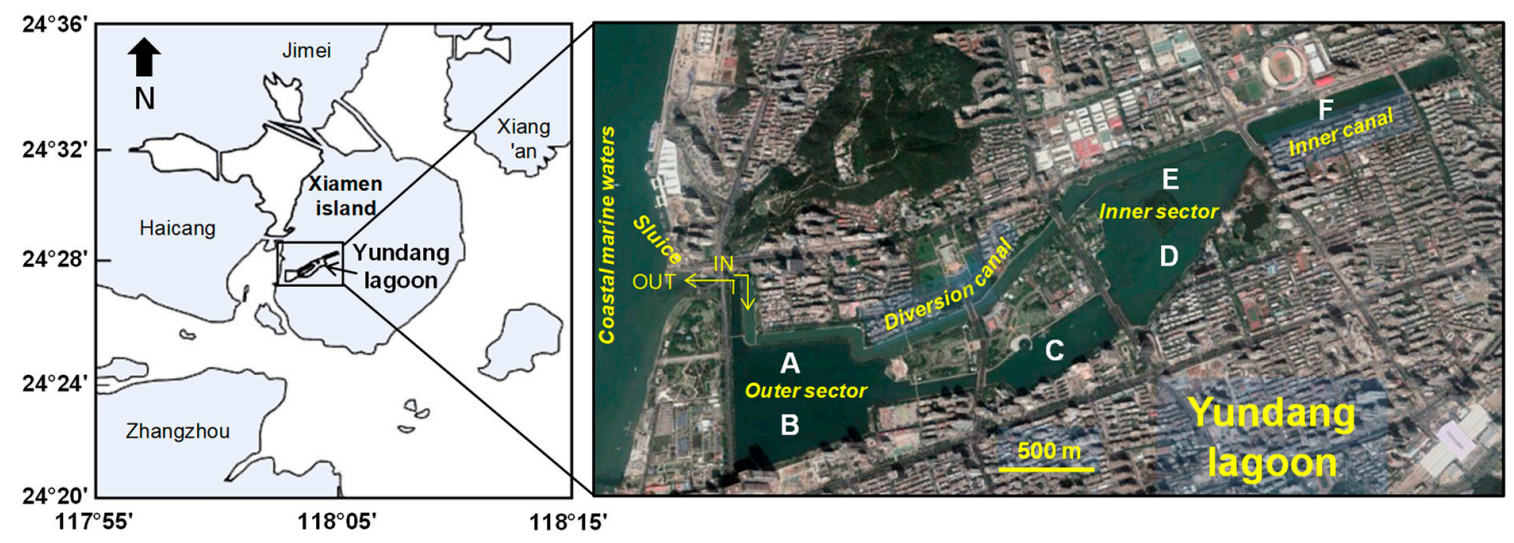

Figure 1. Location of the study area (Xiamen Island, Southeast China) and sampling sites (sites A-F) in the Yundang Lagoon. A schematic representation of water circulation in the Yundang Lagoon is given in [34].

\subsection{Experimental Design and Sampling Activities}

Samples were collected on November 13-14, 2012 at six different sites (A-F) hundreds of meters apart and covering different sectors of the lagoon (Figure 1). Site selection was based on our extensive knowledge of the lagoon's general features [32,34,35]. All sites were characterized by unvegetated soft-bottom sediments with a depth varying from about 1.5-3 meters. At each site, three stations tens of meters apart were randomly chosen and three replicate sediment samples meters apart were collected at each station using a Van Veen grab $(30 \times 20 \mathrm{~cm}$, penetration depth $18 \mathrm{~cm}$, approximate volume of $7 \mathrm{~L}$ ), for a total of 54 samples. Each sediment sample was sieved on a mesh size of $0.5 \mathrm{~mm}$ and the residue was fixed in a 5\% formalin buffered solution for macrozoobenthos determination. Prior to sieving, a subsample of the top $1 \mathrm{~cm}$ of the sediment was collected from each grab to determine water content and grain-size and chemical (total organic carbon and total nitrogen) analysis. These subsamples were kept refrigerated in a cooler-box until further treatment in the laboratory.

At each site and station, water salinity, temperature, and dissolved oxygen (DO) concentrations were measured using a portable CTD cast (YSI 6600) and near-bottom water samples for chemical analysis (nutrients, biological oxygen demand $\left(\mathrm{BOD}_{5}\right)$, chemical oxygen demand $\left(\mathrm{COD}_{\mathrm{Mn}}\right)$, and 
chlorophyll- $a$ (Chl-a)) and suspended solid (SS) determination were collected using a two-liter Niskin bottle, for a total of 18 samples.

\subsection{Sample Treatment and Analysis}

In the laboratory, water samples were filtered using a $0.45 \mu \mathrm{m}$ filter. Nutrients (ammonia, nitrate, nitrite, and reactive phosphorus (RP)), $\mathrm{BOD}_{5}, \mathrm{COD}_{\mathrm{Mn}}$, and $\mathrm{SS}$ were measured by applying standard analytical methods (Table 1) according to the national standard GB17378.4 [36]. Chl- $a$ was measured by fluorometric analysis using a Turner Designs Fluorometer (Mode 10-AU) (San Jose, USA).

Table 1. Methods used for seawater analysis in Yundang Lagoon. All methods are according to the national standard GB17378.4 [36].

\begin{tabular}{|c|c|c|}
\hline Variable & Method & Lower Detection Limit $\left(\mathrm{mg} \mathrm{L}^{-1}\right)$ \\
\hline Ammonia & Indophenol-blue colorimetry & 0.012 \\
\hline Nitrite & $\begin{array}{l}\mathrm{N}(1-\text {-naphty1)-ethylenediamine } \\
\text { dihydrochloride spectrophotometric method }\end{array}$ & 0.0005 \\
\hline Nitrate & Cadmium column reduction method & 0.012 \\
\hline Phosphate & $\begin{array}{l}\text { Phosphomolybdenum blue } \\
\text { spectrophotometric method }\end{array}$ & - \\
\hline $\begin{array}{l}\text { Biological Oxygen Demand } \\
\left(\mathrm{BOD}_{5}\right)\end{array}$ & Five-days biochemical culture method & 2 \\
\hline $\begin{array}{c}\text { Chemical Oxygen Demand } \\
\left(\mathrm{COD}_{\mathrm{Mn}}\right)\end{array}$ & $\begin{array}{l}\text { Potassium iodide-alkaline potassium } \\
\text { permanganate determination method }\end{array}$ & 0.5 \\
\hline Suspended solids (SS) & Weighting & 0.1 \\
\hline
\end{tabular}

For the measurements of sediment particle size, diluted hydrochloric acid and hydrogen peroxide were added to the evenly mixed sample to remove carbonates and organic matter. After being washed to remove the acid to attain neutrality, Na-hexametaphosphate $0.6 \%$ solution was added to avoid particle flocculation, and the samples were allowed to rest for $24 \mathrm{~h}$. Subsequently, the median particle size of sediments (Md) was measured with a Malvern Mastersizer 2000 laser particle size analyzer (Malvern, United Kingdom), and the measurement data were outputted at 1/4 $\Phi$ intervals. The moment method was used to calculate the grain-size parameters of the sediments [37]. The water content (Wc) of the sediment was obtained after drying a sediment subsample at $70{ }^{\circ} \mathrm{C}$ for $24 \mathrm{~h}$. Analysis of total organic carbon (TOC) and total nitrogen (TN) content of sediments was accomplished by freeze-drying and powdering the sediment sample. Carbonate was removed from the sample with $2 \mathrm{~N} \mathrm{HCl}$, at which point it was vacuum-dried. The TOC and TN content of the dried sediment sample was measured using an Elemental vario EL-III element analyzer. Replicate analyses of standards of acetanilide yielded a mean precision of about $0.3 \%$ for organic carbon and nitrogen.

The macrozoobenthos from each grab sample were sorted, identified to the species level, when possible, counted under a stereo-microscope and preserved in $75 \%$ ethanol. After counting, the wet weight was taken for individuals of the same species in each sample.

\subsection{Data Analyses}

In order to evaluate environmental differences among sites, multivariate analyses were carried out on the environmental data using the principal component analysis (PCA) ordination method and correlation matrices [38]. The components loadings were considered to quantify the correlation between the variables and the principal components scores. Water and sediment variables were analyzed separately in order to investigate the trophic features of the Yundang Lagoon from two different perspectives and to evaluate the consistency of results between the two ecosystem components (water and sediment). Near-bottom water variables included salinity, ammonium, nitrate, nitrite, dissolved inorganic nitrogen (DIN = sum of ammonium, nitrate, and nitrite), RP, N/P ratio, DO, $\mathrm{BOD}_{5}, \mathrm{COD}_{\mathrm{Mn}}$, chlorophyll- $a(\mathrm{Chl}-a)$, and suspended solids (SS). Sediment variables included the sand $(>63 \mu \mathrm{m})$, silt $(63-8 \mu \mathrm{m})$ and clay $(<8 \mu \mathrm{m})$ fractions, $\mathrm{Md}, \mathrm{Wc}$, and TOC (TN was excluded from the multivariate analyses as it correlated to TOC at $R>0.90$ ). 
PERMANOVA was used to tests for differences in the arrangement of the sites in terms of biotic parameters (i.e., abundance, number of species, diversity, biomass) and the abundance of individual species [39]. The pairwise post hoc test was also performed for all pairs of site comparisons. The Bonferroni correction was used and 9999 permutations were performed [40]. Differences among sites related to macrozoobenthos data were examined by means of non-metric multidimensional scaling (nMDS) based on the Bray-Curtis similarity matrix. Dominance curves [41] were plotted for each site, and species were ranked in order of importance in terms of percent cumulative abundance. Canonical correspondence analysis (CCA) was performed on macrozoobenthos abundance data (log transformed) and environmental variables (nitrate, ammonium, RP, SS, sand, Md, TOC) at each site, in order to test the response of the macrozoobenthic community to the main environmental (trophic and confinement) gradients to determine what provided the best combination of variables supporting the ordination model [42]. In particular, nitrate, ammonium, and RP for the water and TOC for the sediments were used as trophic variables, while SS for the water and sand and Md for the sediments were used as variables related to the hydrodynamics and confinement of the lagoon.

All statistical analyses were performed by means on the PAST statistics program (version 3.12).

\section{Results}

\subsection{Environmental Variables}

\subsubsection{Water}

Near-bottom water temperature and salinity were homogeneous throughout the lagoon averaging $22.6 \pm 0.2{ }^{\circ} \mathrm{C}$ and $29.9 \pm 0.3 \mathrm{psu}( \pm \mathrm{SE}$ standard error), respectively. Marked spatial variation was found for all the other environmental variables examined (Figure 2). In particular, ammonium, $\mathrm{RP}, \mathrm{BOD}_{5}$, $\mathrm{COD}_{\mathrm{Mn}}$, and $\mathrm{Chl}-a$ concentrations were highest at site $\mathrm{F}$, while nitrate, nitrite and DIN concentrations, and the N/P ratio were lowest at site A. SS concentrations were lowest at both site A and B. Overall, the water variables highlighted the hypertrophic condition of site $\mathrm{F}$, in the innermost sector of the lagoon, as compared to all the other sites. Separation of sites was also clearly revealed by PCA, as site F was separate along the $x$-axis, and sites A and B along the $y$-axis (Figure 3). The PCA loadings showed the highest correlation for ammonium, $\mathrm{RP}, \mathrm{BOD}_{5}, \mathrm{COD}_{\mathrm{Mn}}$, and $\mathrm{Chl}-a$ (positive), and $\mathrm{DO}$ (negative) on the $x$-axis, and the highest (positive) correlation for nitrate, nitrite DIN, N/P, and SS on the $y$-axis (Table 2).

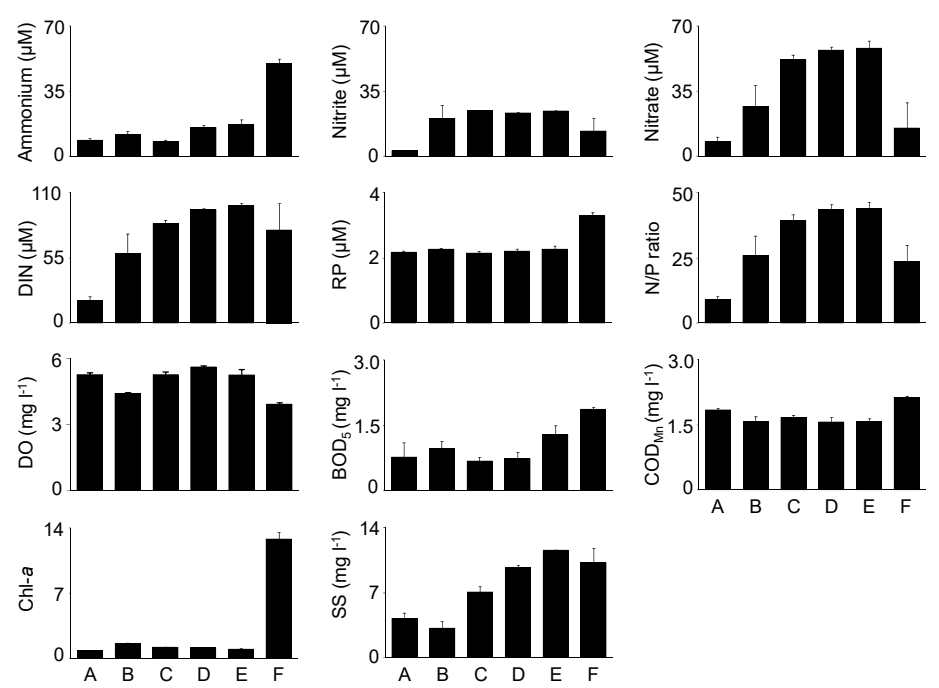

Figure 2. Mean value ( $\mathrm{n}=3 ; \pm \mathrm{SE}$ standard error) of near-bottom water variables at each site: ammonium, nitrate, nitrite, dissolved inorganic nitrogen (DIN = ammonium, nitrate, and nitrite), reactive phosphorous (RP), N/P, dissolved oxygen (DO), biological oxygen demand $\left(\mathrm{BOD}_{5}\right)$, chemical oxygen demand ( $\left.\mathrm{COD}_{\mathrm{Mn}}\right)$, chlorophyll- $a(\mathrm{Chl}-a)$, and suspended solids (SS). 


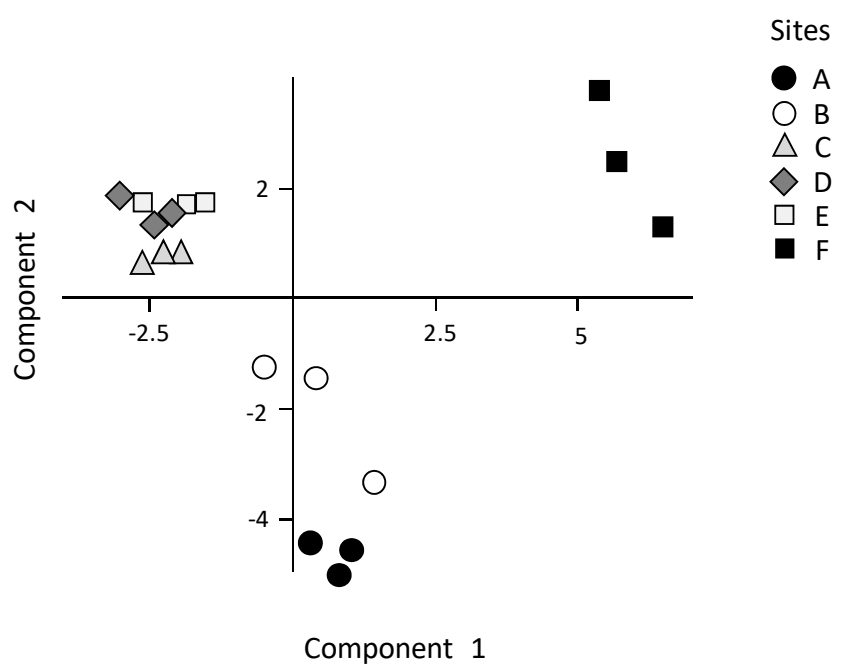

Figure 3. Principal component analysis (PCA) of near-bottom water variables, including salinity, dissolved oxygen (DO), ammonium, nitrate, nitrite, dissolved inorganic nitrogen (DIN = ammonium, nitrate, and nitrite), reactive phosphorus (RP), N/P ratio, suspended solids (SS), biological oxygen demand $\left(\mathrm{BOD}_{5}\right)$, chemical oxygen demand $\left(\mathrm{COD}_{5}\right)$, and chlorophyll- $a(\mathrm{Chl}-a) . \mathrm{PC} 1=46.5 \%$ of variance, PC2 $=34.4 \%$ of variance.

Table 2. Component correlation coefficients in the principal component analysis (PCA) of the water variables and the first two components (PC1 and PC2 $=46.5 \%$ and $34.4 \%$ of variance, respectively).

\begin{tabular}{ccc}
\hline & PC1 & PC2 \\
\hline Salinity & 0.10 & 0.25 \\
Dissolved oxygen & $\mathbf{- 0 . 3 4}$ & -0.03 \\
Nitrate & -0.29 & $\mathbf{0 . 3 4}$ \\
Nitrite & -0.21 & $\mathbf{0 . 3 6}$ \\
Ammonium & $\mathbf{0 . 3 7}$ & 0.24 \\
DIN & -0.11 & $\mathbf{0 . 4 7}$ \\
RP & $\mathbf{0 . 3 8}$ & 0.18 \\
N/P & -0.24 & $\mathbf{0 . 4 0}$ \\
Suspended solids & 0.04 & $\mathbf{0 . 4 0}$ \\
BOD & $\mathbf{0 . 3 2}$ & 0.19 \\
COD & $\mathbf{0 . 3 7}$ & -0.01 \\
Chlorophyll-a & $\mathbf{0 . 3 9}$ & 0.15 \\
\hline
\end{tabular}

In bold, the highest loadings.

\subsubsection{Sediments}

Surface sediments were generally muddy, with a prevalence of silt at all sites (Figure 4). However, spatial differences included higher sand content at sites A and B, compared to C, D, and E (Figure 4). The median particle diameter $(\mathrm{Md})$ varied similarly to the variation in the silt content among sites, with the highest Md values at sites C, D, and E. The water content $(\mathrm{Wc})$ varied less markedly among sites, with the largest within-site variation at site A. Finally, the TOC content did not show marked differences among sites, except at site F. In particular, TOC varied from $1.7 \%$ to $2.3 \%$ at sites A and B, respectively, but was up to $5.0 \pm 0.01$ at site $\mathrm{F}$, providing an additional evidence of its hypertrophic condition (Figure 4). Similar to the water variables, the ordination model of the PCA carried out on the sediment variables revealed a clear separation of site $\mathrm{F}$ along the $y$-axis (Figure 5). Along the $x$-axis, sites $A$ and $B$ were located on the negative pole, opposite to sites $C, D$, and $E$. The observed pattern is consistent with the variation in sediment grain-size among sites $\mathrm{A}-\mathrm{E}$, with higher loadings for sand (negative values) and silt, clay and $\mathrm{Md}$ (positive values) on the $x$-axis. On the contrary, factors related to organic enrichment, found at site F, were mostly correlated with the $y$-axis where Wc (a proxy of mud 
content) and TOC showed a positive and a negative correlation, respectively (Table 3). Overall, these results were consistent with those obtained from the water variables, indicating that both water and sediment components provide consistent data helpful in assessing the environmental heterogeneity and the trophic features of the Yundang Lagoon.
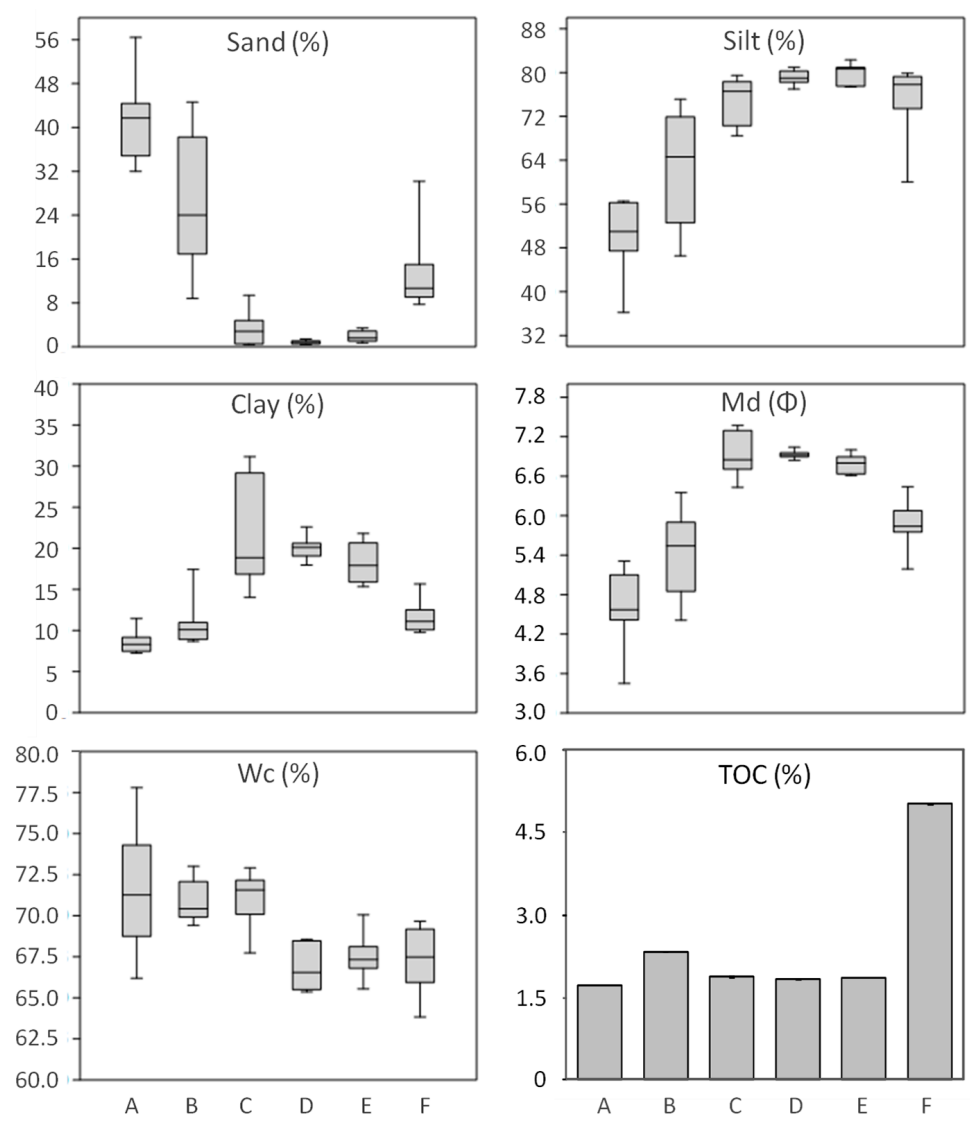

Figure 4. Box-plots of sediment sand, silt and clay content, and median particle diameter (Md) and water content $(\mathrm{Wc})$ at each site $(\mathrm{n}=9)$, as well as the mean value of total organic carbon (TOC) content of sediments at each site $(\mathrm{n}=3, \pm \mathrm{SE}$ standard error not visible when $<0.01)$.

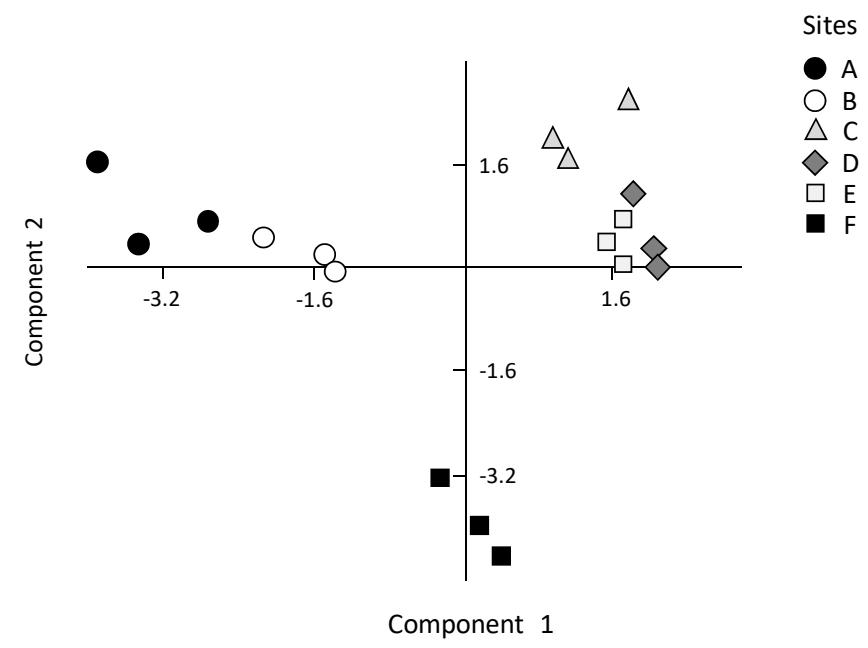

Figure 5. Principal component analysis (PCA) of sediment variables, including sand, silt, and clay content, median particle diameter $(\mathrm{Md})$, and water and total organic carbon content. $\mathrm{PC} 1=67.6 \%$ of variance, $\mathrm{PC} 2=23.9 \%$ of variance. 
Table 3. Component correlation coefficients in the principal component analysis (PCA) of the sediment variables and the first two components (PC1 and PC2 $=67.6 \%$ and $23.9 \%$ of variance, respectively).

\begin{tabular}{ccc}
\hline & PC1 & PC2 \\
\hline Sand & $\mathbf{- 0 . 4 9}$ & 0.00 \\
Silt & $\mathbf{0 . 4 8}$ & -0.17 \\
Clay & $\mathbf{0 . 4 3}$ & 0.36 \\
Md & $\mathbf{0 . 4 8}$ & 0.16 \\
Wc & -0.33 & $\mathbf{0 . 4 6}$ \\
TOC & 0.00 & $\mathbf{- 0 . 7 8}$ \\
\hline
\end{tabular}

In bold, the highest loadings.

\subsection{Macrozoobenthic Assemblages}

In the present study, we found 43 taxa which marked a significant increase in benthic species richness and diversity in the Yundang Lagoon compared to previous years and decades (Table 4). In particular, according to the available published and gray literature, no species were present in the 1980s, a single polychaete, Neanthes succinea, was found in the 1990s, and a few more species ( $\mathrm{n}=9$ ) were reported during the 2000's, with two polychaetes dominating (Neanthes glandicincta and Capitella capitata), and the first report of the invasive bivalve Mytilopsis sallei (Table 4). In our study, M. sallei was the most abundant benthic species, accounting for $75 \%$ of the total individuals and $88 \%$ of the total biomass. Several other less abundant species included the gastropods Stenothyra glabra and Rissolina plicatula, the bivalve Pseudopythina tsurumaru, the crustaceans Corophium sp. and Corophium uenoi, and the polychaete Cossurella dimorpha (Table 4). All these species, except $C$. dimorpha, were found at site A. $M$. sallei was dominant at all stations and replicates of sites A and $\mathrm{C}$, very abundant at a single station of site F, and was not found at sites B, D, and E. Another invasive species, the ascidian Styela plicata, was found only in some replicates of site $\mathrm{C}$, but followed $M$. sallei in terms of its contribution to the total biomass (8.4\%). S. glabra, P. tsurumaru and N. glandicincta occurred at all sites except B and F, while C. dimorpha was dominant in B and absent in A and C. Finally, different subsets of species were exclusive to a single site: nine species in A, four in B, four in C, nine in D and only two in E (Table 4).

The PERMANOVA conducted on the abundance of all species revealed significant differences among sites. Site A was distinct from all the others, while site $C$ differed from $B, D$, and $E$, and site $F$ from D and E (Table 5). These differences were similar to those found for M. sallei which showed the highest abundance and biomass at site A. Significant differences also emerged from the structural biotic parameters, including total abundance, species richness, diversity, and biomass (Table 6, Figure 6). In the pairwise comparisons, site A was significantly different from most of the other sites in terms of total abundance and species richness, and less so in terms of diversity ( $\neq$ from $\mathrm{F}$ ) and biomass ( $\neq$ from B, D, and E) (Table 7). Results suggest that the dominance of $M$. sallei appeared to be one of the discriminating factors responsible for the differentiation of sites and their species richness. In addition, site A had the highest species richness, followed by $C, D$, and E, and was significantly different in terms of diversity from site $\mathrm{F}$ which had the least number of species (Table 7, Figure 6). 
Table 4. Changes in species number and composition of macrozoobenthos collected from the bottom sediment in the Yundang Lagoon in the years before the restoration (1982-1987), and during the first (1989-1992) and the third (2001 to present) phase of restoration. Information prior to the present study (2012) was gathered from Xu et al. [43] for 2007-2008, and from Ye et al. [29] and unpublished reports for the other periods. The dominant species in each period/Site are marked by *. For the present study (2012), the abundance (ind. $600 \mathrm{~cm}^{-2}$ ) per site is also reported as the mean of three stations.

\begin{tabular}{|c|c|c|c|c|c|c|c|c|c|c|c|c|c|}
\hline Species/Year & Taxon & Habitat and/or Trait & 1982-1987 & 1992-1993 & 2001-2002 & $2007-2008$ & 2012 (This study) & $\begin{array}{l}2012 \text { Site } \\
\text { A }\end{array}$ & $\begin{array}{l}2012 \text { Site } \\
\text { B }\end{array}$ & $\begin{array}{l}2012 \text { Site } \\
\text { C }\end{array}$ & $\begin{array}{c}2012 \text { Site } \\
\text { D }\end{array}$ & $\begin{array}{c}2012 \text { Site } \\
\text { E }\end{array}$ & $\begin{array}{c}2012 \text { Site } \\
\text { F }\end{array}$ \\
\hline Mytilopsis sallei (Récluz, 1849) & B & F & & & $\sqrt{ }$ & $\sqrt{ }$ & $\sqrt{*}^{*}$ & $230^{*}$ & & 67.67 & 2 & & 63 \\
\hline Rissoina plicatula Gould, 1861 & G & $\mathrm{F} / \mathrm{M}$ & & & & & $\sqrt{*}$ & $12^{*}$ & & 4.33 & & & \\
\hline Stenothyra glabra Adams, 1861 & G & $\mathrm{M} / \mathrm{S}$ & & & & & $\sqrt{*}$ & $8.67^{*}$ & 1.33 & 0.33 & 4.34 & 3.33 & \\
\hline Corophium uenoi Stephensen, 1932 & c & $\mathrm{F} / \mathrm{S}$ & & & $\sqrt{ }$ & $\sqrt{ }$ & $\sqrt{*}$ & $8.67^{*}$ & & & & & \\
\hline Corophium sp. & C & $\mathrm{F} / \mathrm{S}$ & & & & & $\sqrt{*}$ & $8.67^{*}$ & 1.33 & & & & \\
\hline Pseudopythina tsurumaru (Habe, 1959) & B & C & & & & & $\sqrt{ }^{*}$ & $7.33^{*}$ & & 2.67 & 0.67 & 1 & \\
\hline $\begin{array}{l}\text { Molgula manhattensis (De Kay, 1843) } \\
\text { Samurosis s. }\end{array}$ & $\mathrm{A}$ & F & & & & & $\checkmark$ & 2 & & & & & \\
\hline Gammaropsis sp. & C & S & & & & & $\checkmark$ & 2 & 1 & & & & \\
\hline $\begin{array}{l}\text { Cerithidea sp. } \\
\text { Grandidierella japonica Stephensen, } 1938\end{array}$ & $\mathrm{G}$ & $\underset{S}{\mathrm{M} / \mathrm{S}}$ & & & & & $\sqrt{ }$ & 1.34 & & & & & \\
\hline $\begin{array}{l}\text { Grandidierella japoninac Stephensen, } 1938 \\
\text { Tharyx sp. }\end{array}$ & ${ }_{\mathrm{P}}^{\mathrm{C}}$ & $\begin{array}{l}\text { s } \\
\text { s }\end{array}$ & & & $\sqrt{ }$ & $\sqrt{ }$ & $\begin{array}{l}\mathrm{v} \\
\mathrm{v}\end{array}$ & $\begin{array}{c}1 \\
0.67\end{array}$ & & & & & \\
\hline Diopatra chiliensis Quatrefages, 1865 & $\mathrm{P}$ & $\mathrm{s}$ & & & & & $v$ & 0.33 & & & & & \\
\hline Cephalothrix sp. & $\mathrm{N}$ & $\mathrm{s}$ & & & & & $\sqrt{ }$ & 0.33 & & & & & \\
\hline Cycladicama sp. & B & s & & & & & v & 0.33 & & & & & \\
\hline Neanthes glandicincta (Southern, 1921) & $\mathrm{P}$ & $\mathrm{s}$ & & & $\sqrt{ }$ & $\sqrt{ }^{*}$ & v & 0.33 & & 0.33 & 0.33 & 0.33 & \\
\hline 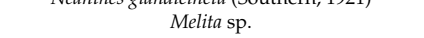 & $\mathrm{C}$ & $\mathrm{s}$ & & & $v$ & $v$ & v & 0.33 & & & & 0.05 & \\
\hline Spionidae und. & $\mathrm{P}$ & $\mathrm{s}$ & & & $\checkmark$ & $\checkmark$ & v & & 0.33 & & & & \\
\hline Terebellides stroemii Sars, 1835 & $\mathrm{P}$ & S/F & & & & & v & & 0.67 & & & & \\
\hline Cossurella dimorpha Hartman, 1976 & $\mathrm{P}$ & $\mathrm{s}$ & & & & & $\sqrt{ }^{*}$ & & $1.33^{*}$ & & 8 & 1.34 & 1.67 \\
\hline Sabellidae und. & $\mathrm{P}$ & $\mathrm{F}$ & & & $\sqrt{ }$ & $\sqrt{ }$ & $\sqrt{ }$ & & 0.67 & 1 & & 0.33 & \\
\hline Pista sp. & $\mathrm{P}$ & $\mathrm{s}$ & & & & & $v$ & & 0.33 & & & & \\
\hline Serpulidae und. & $\mathrm{P}$ & $\mathrm{F}$ & & & & & $\mathrm{v}$ & & 0.33 & & & & \\
\hline Paraprionospio pinnata (Ehlers, 1901) & $\mathrm{P}$ & $\mathrm{M} / \mathrm{S}$ & & & & & $\sqrt{ }$ & & 0.33 & 1.67 & 1 & & \\
\hline Praxillella sp. & $\mathrm{P}$ & $\mathrm{S} / \mathrm{F}$ & & & & & $\mathrm{v}$ & & & 0.33 & & & 0.33 \\
\hline Alitta succinea (Leuckart, 1847) & $\mathrm{P}$ & $\mathrm{s}$ & & $\sqrt{ }$ & & & & & & & & & \\
\hline Neanthes sp. & $\mathrm{P}$ & s & & & & & $\sqrt{ }$ & & & 0.33 & 0.33 & 0.33 & \\
\hline 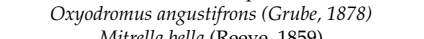 & $\mathrm{P}$ & $\mathrm{M} / \mathrm{S}$ & & & & & v & & & 0.67 & & & \\
\hline Mitrella bella (Reeve, 1859) & G & $\mathrm{F}$ & & & & & $\sqrt{ }$ & & & 1 & & & \\
\hline $\begin{array}{l}\text { Styela plicata (Lesueur, 1823) } \\
\text { Lumbrinereis s }\end{array}$ & $\underset{\mathrm{P}}{\mathrm{A}}$ & F/ & & & & & $\sqrt{v^{*}}$ & & & $\begin{array}{c}4^{*} \\
0.33\end{array}$ & & & \\
\hline Tylorrhynchus heterocheetus (Ouatrefages, 1866) & $\frac{1}{p}$ & $\begin{array}{l}\mathrm{M} / \mathrm{S} \\
\mathrm{M} / \mathrm{S}\end{array}$ & & & & & $\begin{array}{l}v \\
y\end{array}$ & & & & 0.67 & 1.67 & \\
\hline Nitidotellina minuta (Lischke, 1872) & B & $\mathrm{s}$ & & & & & v & & & & 0.33 & & \\
\hline 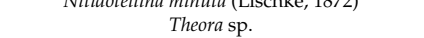 & $\begin{array}{l}\text { D } \\
\text { B }\end{array}$ & s & & & & & v & & & & 0.33 & & \\
\hline Perinereis sp. & $\mathrm{P}$ & $\mathrm{S} / \mathrm{M}$ & & & & & $\sqrt{ }$ & & & & 0.33 & 2 & 0.67 \\
\hline Micronephtys oligobranchia (Southern, 1921) & $\mathrm{P}$ & $\mathrm{M} / \mathrm{S}$ & & & $\sqrt{ }$ & & v & & & & 0.33 & 2 & $0.0 \%$ \\
\hline Eulima bifascialis (Adams, 1864) & G & $\mathrm{P}$ & & & & & v & & & & 0.33 & & \\
\hline Capitella capitata (Fabricius, 1780) & $\mathrm{P}$ & $\mathrm{s}$ & & & $\sqrt{*}$ & $\sqrt{ }^{*}$ & $\sqrt{ }$ & & & & 0.67 & & \\
\hline Poecilochaetus serpens Allen, 1904 & $\mathrm{P}$ & $\mathrm{M} / \mathrm{S}$ & & & & & $\sqrt{ }$ & & & & 0.33 & & \\
\hline Namalycastis abiuma (Grube, 1872) & $\mathrm{P}$ & $\mathrm{S}$ & & & & & v & & & & 1 & & \\
\hline Prionospio queenslandica Blake \& Kudenov, 1978 & $\mathrm{P}$ & $\mathrm{M} / \mathrm{S}$ & & & & & $\sqrt{ }$ & & & & 0.67 & & \\
\hline Potamocorbula ustulata (Reeve, 1844) & B & $\mathrm{M} / \mathrm{S}$ & & & & & $\sqrt{ }$ & & & & 1.34 & 3.33 & 1 \\
\hline Capitellidae und. & $\mathrm{P}$ & $\mathrm{s}$ & & & & & $\sqrt{ }$ & & & & 0.33 & & \\
\hline Perinereis nuntia (Lamarck, 1818) & $\mathrm{P}$ & S/F & & & & & $\sqrt{ }$ & & & & & 1.34 & \\
\hline Potamocorbula laevis (Hinds, 1843) & B & $\mathrm{M} / \mathrm{S}$ & & & $\sqrt{ }$ & $\sqrt{ }$ & & & & & & & \\
\hline Tellinimactra sp. & B & s & & & & & $\mathrm{v}$ & & & & & 0.33 & \\
\hline $\begin{array}{l}\text { Typosyllis sp. } \\
\text { Total number of species }\end{array}$ & $\mathrm{P}$ & $\mathrm{s}$ & 0 & 1 & 9 & $\begin{array}{l}\sqrt{ } \\
9\end{array}$ & 43 & 16 & 10 & 13 & 19 & 11 & 5 \\
\hline
\end{tabular}

Taxon: $\mathrm{B}=$ Bivalves $; \mathrm{G}=$ Gastropods $\mathrm{C}=$ Crustaceans; $\mathrm{P}=$ Polychaetes; $\mathrm{A}=$ Ascidians
$\mathrm{C}=$ Commensal. $\mathrm{B}$. 
Table 5. Results of PERMANOVA (based on Bray-Curtis similarity index) testing differences among sites (A, B, C, D, E, F) for the abundance of all the taxa. Comparisons of post-hoc test between all pairs of sites are also given. Significant comparisons at $p<0.05$ are marked by ${ }^{*}$ and at $p<0.01$ by ${ }^{* *}$. The Bonferroni correction was used. Permutation number $=9999$.

\begin{tabular}{cccccc}
\hline Total sum of squares & 21.88 & & & & \\
Within-group sum of squares & 14.87 & & & & \\
F & 4.533 & & & & \\
$p$ (same) & 0.0001 & & & & \\
\hline Pairwise between sites & $\mathrm{A}$ & $\mathrm{B}$ & $\mathrm{C}$ & $\mathrm{D}$ & $\mathrm{E}$ \\
\hline $\mathrm{B}$ & $0.003^{* *}$ & & & & \\
C & 0.07 & $0.02^{*}$ & & & \\
$\mathrm{D}$ & $0.002^{* *}$ & 0.28 & $0.003^{* *}$ & & \\
E & $0.003^{* *}$ & 1 & $0.005^{* *}$ & 1 & \\
F & $0.03^{*}$ & 0.53 & 0.11 & $0.003^{* *}$ & $0.02^{*}$ \\
\hline
\end{tabular}

Table 6. Results of PERMANOVA (based on Euclidean distance) testing differences among sites for abundance, number of species, Shannon diversity $\left(\mathrm{H}^{\prime}\right)$, and biomass. Permutation number $=9999$. All values are significant at $p<0.0005$.

\begin{tabular}{ccccc}
\hline & Abundance & $\mathrm{N}^{\circ}$ Species & Diversity $\left(\mathrm{H}^{\prime}\right)$ & Biomass \\
\hline Total sum of squares & 9.08 & 249 & 17.37 & 2.18 \\
Within-group sum of & & & & \\
squares & 3.69 & 104.4 & 10.65 & 1.15 \\
Pseudo F & 14.00 & 13.29 & 6.07 & 8.69 \\
$p$ & 0.0001 & 0.0001 & 0.0004 & 0.0001 \\
\hline
\end{tabular}
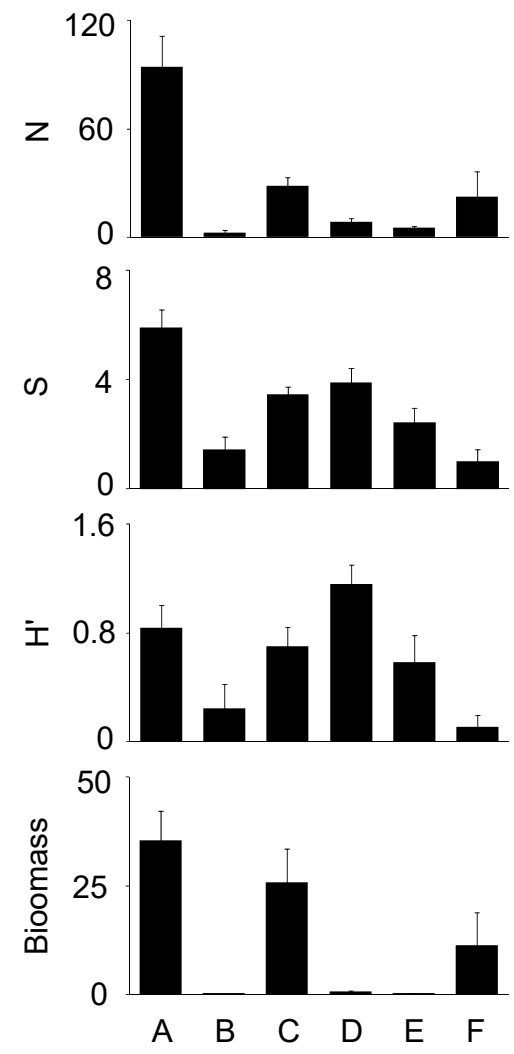

Figure 6. Mean values ( $\mathrm{n}=9 ; \pm \mathrm{SE}$ standard error) of the total number of individuals $\left(\mathrm{N}\right.$, ind. $\left.600 \mathrm{~cm}^{-2}\right)$, total number of species (S), Shannon index $\left(\mathrm{H}^{\prime}\right)$, and biomass (g.wet weight $600 \mathrm{~cm}^{-2}$ ) at each site. 
Table 7. Results of post-hoc test between all pairs of sites. (A-F). Significant comparisons at $p<0.05$ are marked by ${ }^{*}$ and at $p<0.01$ by **. The Bonferroni correction was used.

\begin{tabular}{cccccc}
\hline Abundance & $\mathrm{A}$ & $\mathrm{B}$ & $\mathrm{C}$ & $\mathrm{D}$ & $\mathrm{E}$ \\
\hline $\mathrm{B}$ & $0.002^{* *}$ & & & & \\
$\mathrm{C}$ & $0.01^{* *}$ & $0.006^{* *}$ & & & \\
$\mathrm{D}$ & $0.02^{*}$ & 0.2 & 0.05 & & \\
$\mathrm{E}$ & $0.003^{* *}$ & 1 & $0.02^{*}$ & 1 & 1 \\
$\mathrm{~F}$ & 0.09 & 1 & 1 & 1 & $\mathrm{E}$ \\
\hline $\mathrm{N}^{\circ}$ Species & $\mathrm{A}$ & $\mathrm{B}$ & $\mathrm{C}$ & $\mathrm{D}$ & \\
\hline $\mathrm{B}$ & $0.003^{* *}$ & & & & \\
$\mathrm{C}$ & $0.02^{*}$ & 0.05 & & & \\
$\mathrm{D}$ & 0.52 & 0.07 & 1 & & \\
$\mathrm{E}$ & $0.003^{* *}$ & 1 & 1 & 0,94 & \\
$\mathrm{~F}$ & $0.002^{* *}$ & 1 & $0.02^{*}$ & $0.04^{*}$ & 1 \\
\hline Diversity $\left(\mathrm{H}^{\prime}\right)$ & $\mathrm{A}$ & $\mathrm{B}$ & $\mathrm{C}$ & $\mathrm{D}$ & $\mathrm{E}$ \\
\hline $\mathrm{B}$ & 0.42 & & & & \\
$\mathrm{C}$ & 1 & 0.963 & & & \\
$\mathrm{D}$ & 1 & $0.046^{*}$ & 0.628 & & \\
$\mathrm{E}$ & 1 & 1 & 1 & 0.513 & \\
F & $0.01^{* *}$ & 1 & $0.04^{*}$ & $0.009^{* *}$ & 0.77 \\
\hline Biomass & $\mathrm{A}$ & $\mathrm{B}$ & $\mathrm{C}$ & $\mathrm{D}$ & $\mathrm{E}$ \\
\hline $\mathrm{B}$ & $0.003^{* *}$ & & & & \\
$\mathrm{C}$ & 1 & $0.001^{* *}$ & & 1 & \\
$\mathrm{D}$ & $0.001^{* *}$ & $0.016^{*}$ & $0.02^{*}$ & & \\
$\mathrm{E}$ & $0.001^{* *}$ & 0.7 & $0.006^{* *}$ & 1 & \\
F & 0.44 & 1 & 1 & 1 & \\
\hline
\end{tabular}

Different aspects of diversity, i.e., species richness and the even distribution of individuals over the species, differently affected the benthic distribution patterns of the study sites, as shown by the cumulative dominance curves (Figure 7). The most even distribution in the number of individuals among species was exhibited by site $\mathrm{B}$ (low species richness and low diversity), $\mathrm{D}$ (high species richness and highest diversity), and $\mathrm{E}$ (intermediate between $\mathrm{B}$ and $\mathrm{D}$ in terms of species richness and diversity). Instead, the highest abundances of $M$. sallei mostly affected the dominance curve of sites A and C notwithstanding their high species richness (highest at site A). Finally, the short and flattened curve for site $F$ reflected both the lowest number of species $(n=5)$ observed and the high number of $M$. sallei individuals which occurred at one of its three stations.

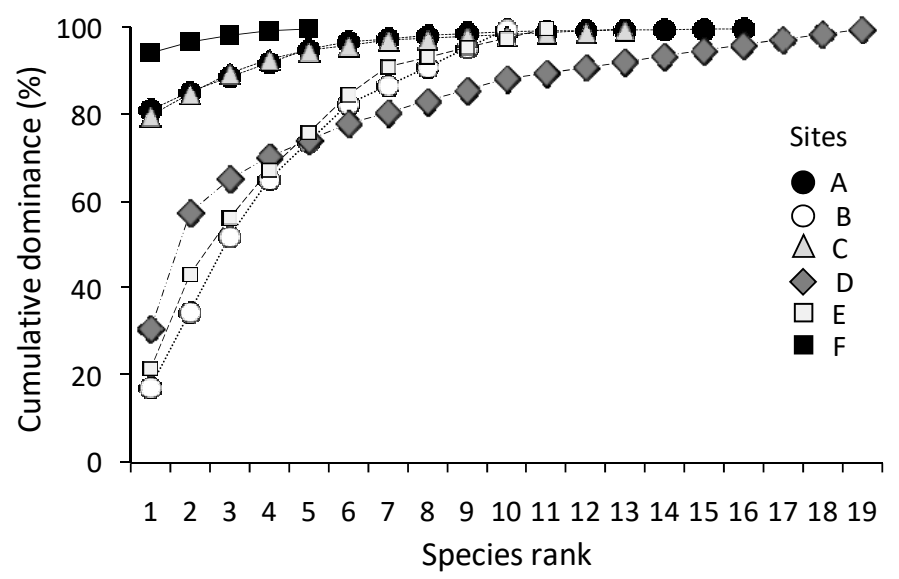

Figure 7. Cumulative dominance curves on macrobenthic abundance data from each sampling site. 
The separation of sites based on the macrobenthos structure was revealed by the MDS (Figure 8). The low level of stress $(=0.05)$ confirmed that there was a good representation of the community pattern. Site A was most markedly distinguished from all the other sites, with the exception of one station of site F dominated by M. sallei, while both sites A and C were clearly separated from the other sites. The significance of differences among the sites was confirmed by the PERMANOVA (Table 5). Canonical correspondence analysis (CCA) revealed the relationship between the selected environmental variables and the ordination model produced (Figure 9). The first two axes accounted for $69.1 \%$ of the explained variability $(51.5 \%$ and $17.6 \%$ for the $x$ - and $y$-axes, respectively). The environmental variables were plotted as correlations with site scores and the strongest correlations were found for sand (negative) and for SS, Md, nitrate, and RP (positive); TOC was less correlated with the axes. Overall, the environmental variables mostly affecting the separation of sites were those connected with the trophic and hydrodynamic features of the inner lagoon sites (D, E), with sand vs. $\mathrm{Md}$ and SS in opposite directions to indicate, as proxies, higher and lower hydrodynamics, respectively (Figure 9).

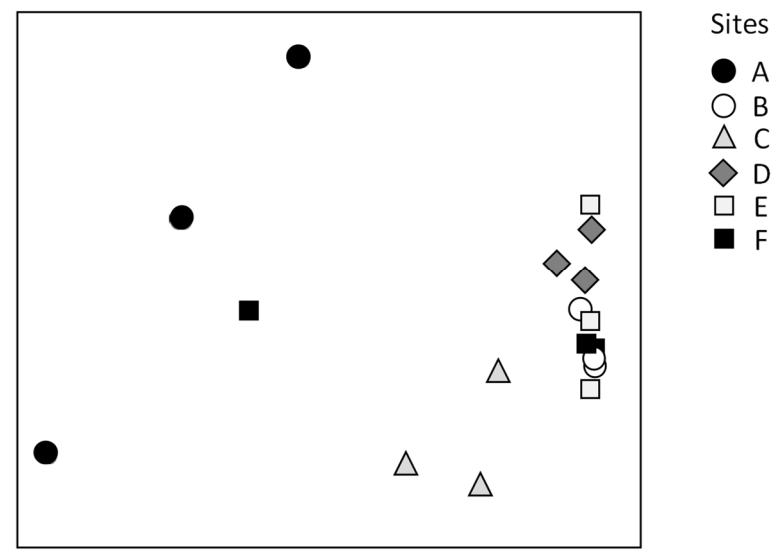

Figure 8. Non-metric multidimensional scaling (nMDS) ordination model of log transformed abundance data (stress: 0.05). Each symbol represents a sampling station at each site obtained as the mean of three replicate samples.

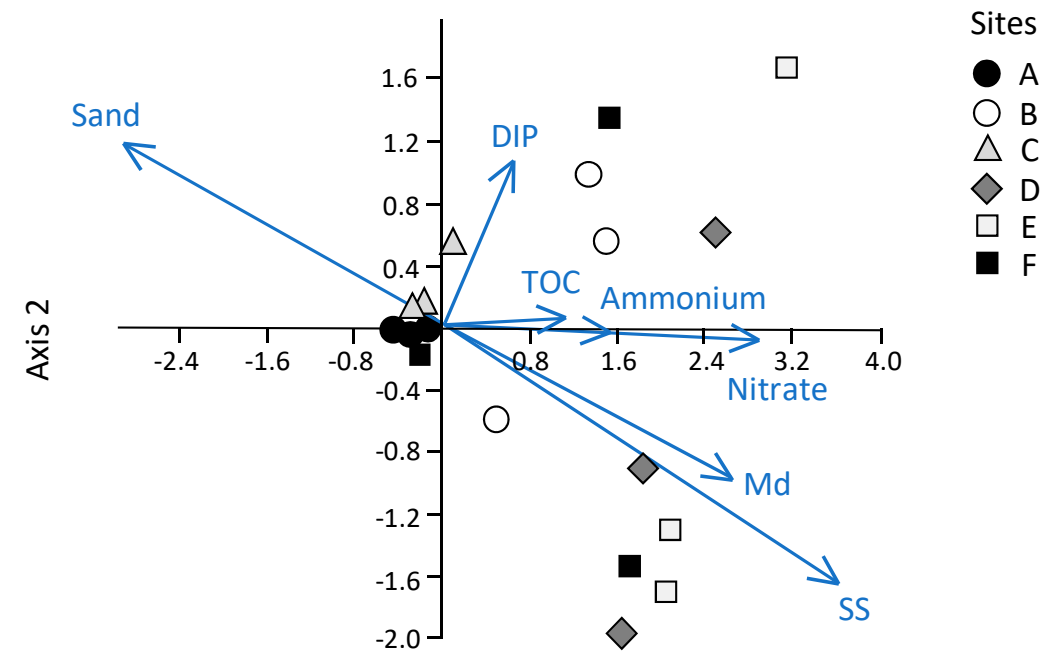

Axis 1

Figure 9. Plot of Canonical correspondence analysis (CCA) performed on species abundance and environmental variables most correlated with two axes and indicative of trophic (i.e., ammonia, nitrate, reactive phosphorus, and TOC) and hydrodynamic (i.e., suspended solids, sand, and size-particle) conditions. 


\section{Discussion}

For the first time, this study assesses the trophic features and benthic diversity of the Yundang Lagoon, an urban coastal lagoon in Southeast China, in a comprehensive and integrated manner. The Yundang Lagoon was referred to as a "dead" lagoon in the 1970s, and has undergone 30-year restoration effort. Microbiological and eco-toxicological studies conducted in the last decade suggest that the recovery of the Yundang Lagoon has not yet been accomplished. In particular, high levels of heavy metals and estrogenic compounds originating mainly from municipal wastewaters have been found in sediments and pore-water of the Yundang Lagoon posing serious toxic risk to the biota including humans [44-46]. Furthermore, evidence has shown that the discharge of surrounding sewage is still a major source of OM pollution in the Yundang Lagoon $[34,46]$.

These results provide a detailed analysis of the trophic features of the Yundang Lagoon and highlight the high spatial heterogeneity of both abiotic (water and sediments) and biotic (macrozoobenthos) components, in spite of its small size and the absence of a salinity gradient. From an abiotic perspective, both water and sediment variables independently point in the same direction. In particular, there was a major separation between the low-nutrient and sandier sites $\mathrm{A}$ and B in the outer sector of the lagoon, and the hypertrophic and organically over-enriched site $\mathrm{F}$ in the inner canal. Site F departed the most from all the other sites, which was consistent with the fact that this sector of the lagoon is still subjected to numerous sewage discharges [32,47]. The confined location and reduced hydrodynamics of site $\mathrm{F}$ are indicated by high levels of suspended solids in the near-bottom water and a high silt content in surface sediments, making the site likely to favor the accumulation of toxic by-products derived from the microbial decomposition of high amounts of OM which were present above established critical thresholds [24,25]. Indeed, higher $\mathrm{BOD}_{5}$ and $\mathrm{COD}_{\mathrm{Mn}}$ concentrations measured at this site (where we also observed methane bubbling from the sediment) may be a concurrent evidence of high saprobity levels in this sector of the lagoon which, in turn, will severely affect the biota [18]. On the other hand, all other sites of the lagoon showed significantly lower Chl- $a$ (in water) and TOC (in sediment) concentrations than those found at site F, notwithstanding seasonal variation, which was not considered here, during phytoplankton blooms [34]. Interestingly, our results are consistent with those reported by Sun et al. [33] who found spatial variation in Chl- $a$ and TOC to be greater in highly urbanized watersheds such as Yundang Lagoon, than in less urbanized watersheds. Overall, our study demonstrates that at the time samples were taken for this study (2012), the Yundang Lagoon had much lower nutrient, $\mathrm{BOD}_{5}$, and $\mathrm{COD}_{\mathrm{Mn}}$ concentrations than those found in previous decades [29], supporting the inference that a partial, but significant environmental recovery has occurred.

The overall improvement of the environmental condition of the Yundang Lagoon was reflected in a major recovery and revitalization of the lagoon's soft-bottom benthic assemblage during the last decade. Following anoxic and azoic sediments found when the lagoon was highly polluted and closed to the adjacent coastal waters until 1987 [29], a single polychaete species, Neanthes succinea, typical of organically enriched sediments with high $\mathrm{H}_{2} \mathrm{~S}$ content $[14,48]$, was reported during the first phase of the restoration program (1989-1992). Between 2001 and 2008, nine species started to colonize the lagoon's sediments [43]. Among them, the opportunistic polychaetes Capitella capitata and Neanthes glandicincta, typical of muddy, organically enriched sediments were dominant, while they occurred with few individuals in our study. These results show a significant recovery of the macrozoobenthic assemblages for the first time, with a marked increase in species richness and diversity, yet a heterogeneous distribution across the lagoon. Of the 43 species found, eight were dominant (accounting for 93\% of the total abundance), mainly represented by mollusks and amphipods, and including the polychaete Cossurella dimorpha which was not reported previously. Overall, the most dominant species was the bivalve Dreissenidae Mytilopsis sallei, an invasive alien species native to the Caribbean and a massive component of fouling events [49,50]. M. sallei was transported to China via ballast waters, and was first recorded in Xiamen waters (Maluan Bay) in 1990 and in the Yundang Lagoon in 2000 [51-53]. In a basin as small as the Yundang Lagoon, one may expect little spatial 
variation in the soft-bottom benthic assemblages. However, our extensive sampling effort allowed us to identify significant variation in the macrozoobenthic assemblages within relatively short distances of a few hundred meters. A number of environmental and biological factors may help explaining the high spatial variability and the recovery of the macrozoobenthic assemblages in the Yundang Lagoon. These are: (1) the heterogeneous morphology and the peculiar hydrology of the lagoon, including the daily water exchange with the adjacent coastal sea, (2) the high environmental variability in water and sediments across the lagoon, (3) the presence of nonpoint sources of pollution and other anthropogenic pressures, and (4) the dominance of the invasive $M$. sallei and the biotic interactions within the benthic community. Thus, the present work represents a unique case-study to evaluate the complex dynamics of macrozoobenthic assemblages in a formerly dead urban coastal lagoon following long-term restoration.

As an example, sites A and B in the outer sector of the lagoon, although similar in several environmental features and, thus, significantly different from the other sites, were the least similar to one another in terms of benthic species composition, richness and diversity. In particular, site A was the most abundant, biomass-rich, and species-rich site in the lagoon, while the opposite was true for site B, which had a species richness and diversity as low as that found at the most degraded site, F. We infer that such biotic differences between sites A and B may be related to their position within the outer sector of the lagoon. In particular, site B was located near the heavily modified shoreline made by a concrete wall, following earlier dredging and reclamation, which may have left little of the historic ecohydrological system on this site of the lagoon. This may have contributed to determine a poor macrozoobenthic assemblage which included few species typical of muddy sediments, such as Cossurella dimorpha, Corophium sp. and Gammaropsis sp. On the other hand, site A was located closer to the shoreline where mangrove species, such as Kandelia candel, Avicennia marina, Rhizophora stylosa, and Heritiera littoralis, had been successfully planted from 2001 to 2006 [54], contributing to increases of birds and fish species in the lagoon [29]. It is likely that the presence of mangroves along this shore has favored the colonization of the invasive fouling species $M$. sallei. This bivalve was associated with the richest benthic assemblage of the lagoon, correlating with the highly diverse assemblages found at site A which also included species typical of mangrove habitats such as R. plicatula and S. glabra. The diversity of the site was also seen in Corophium uenoi, which lives within muddy tubes on soft bottom sediments, but is also present in the fouling community, and P. tsurumaru, which is typical of muddy sediments and possibly shares the burrow of holothurian or crabs (commensal). On the contrary, the innermost site $\mathrm{F}$ had the most impoverished assemblage, consistent with its degraded condition in both water and sediments. Yet, M. sallei was also found at one station at this site, providing evidence of its high resistance and resilience, and its ability to settle when a substrate is available, owing to the characteristic traits of opportunistic $r$-strategists [49,50]. The apparently random distribution of M. sallei, heavily colonizing some sectors of the lagoon, was also indicated by its dominance at site C, where environmental conditions were intermediate between the outer (sites A and B) and the innermost (site F) sectors. This indicates that, in addition to the environmental factors, species-specific biological interactions should be considered to evaluate the complex dynamics that occur within a benthic assemblage.

Our results suggest that $M$. sallei, known as an invasive ecosystem engineer that creates new habitats and favors the settlement of other species [55], may support a rich and diversified community. In particular, in the present study M. sallei was associated with the highest number of species having different biological traits (e.g., fouling, parasite and commensal) and typical of different habitats (e.g., muddy sediments, mangroves). Among them, S. glabra, an IUCN threatened species [56] in need of protection measures, and $P$. tsurumaru which is known to establish symbiotic relations with other species [57]. Nevertheless, $M$. sallei is also well known as a pest species characterized by wide temperature, salinity, and oxygen tolerances, as well as a fast growth-rate and a high fecundity which may favor competition with native species and inhibit the growth of other species [49]. As an example, an experimental field study on the fouling macrofauna associated with $M$. sallei conducted in the 
Yundang Lagoon showed a reduction in species diversity in summer when environmental conditions worsened, but the density and biomass of both $M$. sallei and fouling macrofauna were highest [52]. Furthermore, M. sallei is known to erode fishing facilities and artificial structures leading to ecosystem damage, economic loss, and inconvenience to locals [53], thus, its spatial and temporal variation should be carefully monitored.

With regards to the spatiotemporal evolution of the macrozoobenthic assemblages in the Yundang Lagoon, one possibility is an even more massive colonization of the lagoon by $M$. sallei as the most dominant species. The successful establishment of $M$. sallei in the Yundang Lagoon may prefigure a wider, yet probably overlooked colonization of this species as a structural component of the benthic assemblages in other Chinese coastal waters and lagoons for which information is very scant [53]. A similar colonization process occurred in the Mediterranean Sea during the first half of the last century by Serpulidae Ficopomatus enigmaticus which is now a typical bioengineer species in Mediterranean lagoons [58-60]. However, after a period of dominance, M. sallei may decrease in dominance or even be replaced by other species typical of sessile fouling, such as S. plicata. A similar alternation of species has been found between the mussel Mytilus edulis and the polychaete Sabellaria spinulosa along the eastern Atlantic coast, and in the Mediterranean Sea between M. galloprovincialis and the extensive bioconstructions of S. spinulosa along the Italian Puglia coast $[61,62]$.

\section{Conclusions}

The present study highlighted the central role of soft-bottom macrozoobenthic assemblages and associated water and sediment variables in assessing the environmental status of the Yundang Lagoon following the massive restoration effort conducted over the past 30 years. We believe that the macrozoobenthos, which greatly contributed to the lagoon's recovery, will also have a future role in the evolution of the lagoon's biodiversity and functioning, especially considering the dominance of invasive alien species. In particular, the presence of $M$. sallei as a dominant species may be of concern for its possible role as a pest species, thus its spatiotemporal evolution should be carefully monitored. Our results provide valuable, data-based knowledge of the environmental quality, as well as early warning, detection, and prevention of any invasion process in the Yundang Lagoon, an area of special relevance for current legislation. Overall, the environmental and biological information gathered in the present study provides insights relevant to both the activities carried out within the long-term integrated management program, and the forecast of possible future ecological scenarios for the lagoon. As such, these results can support the local administration as they strive towards proper management of the lagoon and the restoration of the ecosystem services that this urban water body may provide.

Author Contributions: Supervision, data curation. and funding acquisition: P.M. and H.L.; investigation: P.M.; H.L., D.G. and C.L.; formal analysis: P.M., S.C. and M.F.G.; visualization: P.M. and M.F.G.; writing-original draft: P.M. and M.F.G.; writing—review and editing: P.M., S.C., M.F.G., D.G., C.L. and H.L.

Funding: The present study was carried out under the Executive Program of Scientific and Technological Cooperation between Italy and China (2010-2012) of the Ministry of Foreign Affairs of Italy granted to PM and LH, and the Short Term Mobility Program (STM-2015) of the National Research Council of Italy granted to PM and LH. The study was also partially funded by the National Key R and D Program of China (grant no. 2016YFC0502904).

Acknowledgments: We gratefully thank Shiqiang Zhou for help in macrozoobenthos identification, the staff of the Xiamen Yundang Lagoon Management Office for logistic and technical support, and Marcello Giorgi, University of Rome "Tor Vergata", for technical support in data analysis procedures. We gratefully acknowledge three anonymous reviewers whose comments greatly contributed to an improved version of the original manuscript.

Conflicts of Interest: The authors declare no conflict of interest.

\section{References}

1. Basset, A.; Elliott, M.; West, R.J.; Wilson, J.G. Estuarine and lagoon biodiversity and their natural goods and services. Estuar. Coast. Shelf Sci. 2013, 132, 1-4. [CrossRef]

2. Marcos, C.; Torres, I.; Lopez-Capel, A.; Perez-Ruzafa, A. Long term evolution of fisheries in a coastal lagoon related to changes in lagoon ecology and human pressures. Rev. Fish Biol. Fish. 2015, 25, 689-713. [CrossRef] 
3. Newton, A.; Brito, A.C.; Icely, J.D.; Derolez, V.; Clara, I.; Angus, S.; Béjaoui, B.; Sousa, A.I.; Solidoro, C.; Yamamuro, M.; et al. Assessing, quantifying and valuing the ecosystem services of coastal lagoons. J. Nat. Conserv. 2018, 44, 50-65. [CrossRef]

4. da Cunha, L.; Wasserman, J.C. Relationships between nutrients and macroalgal biomass in a Brazilian coastal lagoon: The impact of a lock construction. Chem. Ecol. 2003, 19, 283-298. [CrossRef]

5. Como, S.; Magni, P.; Casu, D.; Floris, A.; Giordani, G.; Natale, S.; Fenzi, G.A.; Signa, G.; De Falco, G. Sediment characteristics and macrofauna distribution along a human-modified inlet in the Gulf of Oristano (Sardinia, Italy). Mar. Poll. Bull. 2007, 54, 733-744. [CrossRef] [PubMed]

6. Gong, W.; Shen, J.; Jia, J. The impact of human activities on the flushing properties of a semi-enclosed lagoon: Xiaohai, Hainan, China. Mar. Environ. Res. 2008, 65, 62-76. [CrossRef] [PubMed]

7. Ayache, F.; Thompson, J.R.; Flower, R.J.; Boujarra, A.; Rouatbi, F.; Makina, H. Environmental characteristics, landscape history and pressures on three coastal lagoons in the Southern Mediterranean Region: Merja Zerga (Morocco), Ghar El Melh (Tunisia) and Lake Manzala (Egypt). Hydrobiologia 2009, 622, 15-43. [CrossRef]

8. Mendes, C.L.T.; Soares-Gomes, A. Macrobenthic community structure in a Brazilian chocked lagoon system under environmental stress. Zoologia 2011, 28, 365-378. [CrossRef]

9. Hung, J.J.; Huang, W.C.; Yu, C.S. Environmental and biogeochemical changes following a decade's reclamation in the Dapeng (Tapong) Bay, southwestern Taiwan. Estuar. Coast. Shelf Sci. 2013, 130, 9-20. [CrossRef]

10. Magni, P.; Draredja, B.; Melouah, K.; Como, S. Patterns of seasonal variation in lagoonal macrozoobenthic assemblages (Mellah lagoon, Algeria). Mar. Environ. Res. 2015, 109, 168-176. [CrossRef]

11. Magni, P.; Como, S.; Kamijo, A.; Montani, S. Effects of Zostera marina on the patterns of spatial distribution of sediments and macrozoobenthos in the boreal lagoon of Furen (Hokkaido, Japan). Mar. Environ. Res. 2017, 131, 90-102. [CrossRef] [PubMed]

12. Viaroli, P.; Bartoli, M.; Giordani, G.; Naldi, M.; Orfanidis, S.; Zaldivar, J.M. Community shifts, alternative stable states, biogeochemical controls and feedbacks in eutrophic coastal lagoons: A brief overview. Aquat. Conserv. Mar. Freshw. Ecosyst. 2008, 18, S105-S117. [CrossRef]

13. Magni, P.; Rajagopal, S.; van der Velde, G.; Fenzi, G.; Kassenberg, J.; Vizzini, S.; Mazzola, A.; Giordani, G. Sediment features, macrozoobenthic assemblages and trophic relationships $\left(\delta^{13} \mathrm{C}\right.$ and $\delta^{15} \mathrm{~N}$ analysis $)$ following a dystrophic event with anoxia and sulphide development in the Santa Giusta lagoon (western Sardinia, Italy). Mar. Poll. Bull. 2008, 57, 125-136. [CrossRef] [PubMed]

14. Kanaya, G.; Nakamura, Y.; Koizumi, T.; Yamada, K. Seasonal changes in infaunal community structure in a hypertrophic brackish canal: Effects of hypoxia, sulfide, and predator-prey interaction. Mar. Environ. Res. 2015, 108, 14-23. [CrossRef] [PubMed]

15. Kanaya, G.; Uehara, T.; Kikuchi, E. Effects of sedimentary sulfide on community structure, population dynamics, and colonization depth of macrozoobenthos in organic-rich estuarine sediments. Mar. Poll. Bull. 2016, 109, 393-401. [CrossRef] [PubMed]

16. Kolkwitz, R.; Marsson, M. Ökologie der tierischen Saprobien. Int. Rev. der Gesamten Hydrobiol. Hydrogr. 1909, 2, 126-152. (In German) [CrossRef]

17. Sládeček, V. The future of the saprobity system. Hydrobiologia 1965, 25, 518-537. [CrossRef]

18. Tagliapietra, D.; Sigovini, M.; Magni, P. Saprobity: A unified view of benthic succession models for coastal lagoons. Hydrobiologia 2012, 686, 15-28. [CrossRef]

19. Remane, A. Ecology of brackish water. In Biology of Brackish Water, 2nd ed.; Remane, A., Schlieper, C., Eds.; Schweizer-bart'sche: Stuttgart, Germany, 1971; pp. 1-210.

20. Guelorget, O.; Perthuisot, J.P. Paralic ecosystems. Biological organization and functioning. Vie Milieu 1992, 42, 215-251.

21. Magni, P.; Micheletti, S.; Casu, D.; Floris, A.; Giordani, G.; Petrov, A.N.; De Falco, G.; Castelli, A. Relationship between chemical characteristics of sediments and macrofaunal communities in the Cabras lagoon (Western Mediterranean, Italy). Hydrobiologia 2005, 550, 105-119. [CrossRef]

22. Semprucci, F.; Gravina, M.F.; Magni, P. Meiofaunal Dynamics and Heterogeneity along Salinity and Trophic Gradients in a Mediterranean Transitional System. Water 2019, 11, 1488. [CrossRef]

23. Magni, P. Biological benthic tools as indicators of coastal marine ecosystems health. Chem. Ecol. 2003, 19, 363-372. [CrossRef] 
24. Hyland, J.; Balthis, L.; Karakassis, I.; Magni, P.; Petrov, A.; Shine, J.; Warwick, R.; Vestergaard, O. Organic carbon content of sediments as an indicator of stress in the marine benthos. Mar. Ecol. Prog. Ser. 2005, 295, 91-103. [CrossRef]

25. Magni, P.; Tagliapietra, D.; Lardicci, C.; Balthis, L.; Castelli, A.; Como, S.; Pessa, G.; Rismondo, A.; Viaroli, P.; Tataranni, M.; et al. Animal-sediment relationships: Evaluating the 'Pearson-Rosenberg paradigm' in Mediterranean coastal lagoons. Mar. Poll. Bull. 2009, 58, 478-486. [CrossRef] [PubMed]

26. Foti, A.; Fenzi, G.; Di Pippo, F.; Gravina, M.F.; Magni, P. Testing the saprobity hypothesis in a Mediterranean lagoon: Effects of confinement and organic enrichment on benthic communities. Mar. Environ. Res. 2014, 99, 85-94. [CrossRef] [PubMed]

27. Chen, L.; Ren, C.; Zhang, B.; Li, L.; Wang, Z.; Song, K. Spatiotemporal dynamics of coastal wetlands and reclamation in the Yangtze estuary during past 50 years (1960s-2015). Chin. Geogr. Sci. 2018, 28, 386-399. [CrossRef]

28. Borja, A.; Bricker, S.B.; Dauer, D.M.; Demetriades, N.T.; Ferreira, J.G.; Forbes, A.T.; Zhu, C.; Hutchings, P.; Marques, J.C.; Kenchington, R. Overview of integrative tools and methods in assessing ecological integrity in estuarine and coastal systems worldwide. Mar. Poll. Bull. 2008, 56, 1519-1537. [CrossRef]

29. Ye, G.; Chou, L.M.; Hu, W. The role of an integrated coastal management framework in the long-term restoration of Yundang Lagoon, Xiamen, China. J. Environ. Plan. Man. 2014, 57, 1704-1723. [CrossRef]

30. Lu, Z.B.; Du, Q.; Huang, Y.J. Ecological effects of Integrated Management on Yundang Lake in Xiamen. J. Oceanogr. Taiwan Strait. 1997, 16, 306-310. (In Chinese)

31. Zhang, X.; Xue, X. Analysis of marine environmental problems in a rapidly urbanising coastal area using the DPSIR framework: A case study in Xiamen, China. J. Environ. Plan. Manag. 2013, 56, 720-742. [CrossRef]

32. Huang, L.F.; Zhuo, J.F.; Guo, W.D.; Spencer, R.G.M.; Zhang, Z.Y.; Xu, J. Tracing organic matter removal in polluted coastal waters via floating bed phytoremediation. Mar. Pollut. Bull. 2013, 71, 74-82. [CrossRef] [PubMed]

33. Sun, Y.W.; Guo, Q.H.; Liu, J.; Wang, R. Scale Effects on Spatially Varying Relationships Between Urban Landscape Patterns and Water Quality. J. Environ. Manag. 2014, 54, 272-287. [CrossRef] [PubMed]

34. Zheng, X.; Como, S.; Magni, P.; Huang, L. Spatiotemporal variation in environmental features and elemental/isotopic composition of organic matter and primary producers in the Yundang lagoon (Xiamen, China). Environ. Sci. Pollut. Res. 2019, 26, 13126-13137. [CrossRef] [PubMed]

35. Guo, W.; Xu, J.; Wang, J.; Wen, Y.; Zhuo, J.; Yan, Y. Characterization of dissolved organic matter in urban sewage using excitation emission matrix fluorescence spectroscopy and parallel factor analysis. J. Environ. Sci. China 2010, 22, 1728-1734. [CrossRef]

36. National standard GB17378.4-2007. The Specification for Marine Monitoring, Part 4: Seawater Analysis; Standards Press of China: Beijing, China, 2007.

37. McManus, J. Grain size determination and interpretation. In Techniques in Sedimentology; Tucker, M., Ed.; Black-Well: Oxford, UK, 1988; pp. 63-85.

38. Davis, J.C. Statistics and Data Analysis in Geology; John Wiley \& Sons: New York, NY, USA, 1986.

39. Anderson, M.J. A new method for non-parametric multivariate analysis of variance. Austral. Ecol. 2001, 26, $32-46$.

40. Rice, W.R. Analyzing tables of statistical tests. Evolution 1989, 43, 223-225. [CrossRef] [PubMed]

41. Clarke, K.R. Comparisons of dominance curves. J. Exp. Mar. Biol. Ecol. 1990, 138, 143-157. [CrossRef]

42. Clarke, K.R.; Ainsworth, M. A method of linking multivariate community structure to environmental variables. Mar. Ecol. Prog. Ser. 1993, 92, 205-219. [CrossRef]

43. Xu, Y.B.; Li, X.Z.; Wu, L.F.; Qian, X.M.; Zheng, H.D.; Cai, J.D. Investigation and assessment on the macrobenthos of Yundang Lake in Xiamen. J. Fujian Fish. 2009, 2, 17-23. (In Chinese)

44. Yan, C.; Li, Q.; Zhang, X.; Li, G. Mobility and ecological risk assessment of heavy metals in surface sediments of Xiamen Bay and its adjacent areas, China. Environ. Earth Sci. 2009, 60, 1469-1479. [CrossRef]

45. Chen, C.; Lu, Y.; Hong, J.; Ye, M.; Wang, Y.; Lu, H. Metal and metalloid contaminant availability in Yundang Lagoon sediments, Xiamen Bay, China, after 20 years continuous rehabilitation. J. Hazard. Mater. 2010, 175, 1048-1055. [CrossRef] [PubMed]

46. Zhang, X.; Gao, Y.J.; Li, Q.Z.; Li, G.X.; Guo, Q.H.; Yan, C.Z. Estrogenic compounds and estrogenicity in surface water, sediments, and organisms from Yundang Lagoon in Xiamen, China. Arch. Environ. Contam. Toxicol. 2011, 61, 93-100. [CrossRef] [PubMed] 
47. Zhuo, J.; Guo, W.; Deng, X.; Zhang, Z.; Xu, J.; Huang, L. Fluorescence excitation-emission matrix spectroscopy of CDOM from Yundang Lagoon and its indication for organic pollution. Spectrosc. Spect. Anal. 2010, 30, 1539-1544.

48. Como, S.; Magni, P. Temporal changes of a macrobenthic assemblage in harsh lagoon sediments. Estuar. Coast. Shelf Sci. 2009, 83, 638-646. [CrossRef]

49. Morton, B. The biology and functional morphology of Mytilopsis sallei (Recluz) (Bivalvia: Dreissenacea) fouling Visakhapatnam harbour, Andhra Pradesh, India. J. Molluscan Stud. 1981, 47, 25-42. [CrossRef]

50. Morton, B. Life-history characteristics and sexual strategy of Mytilopsis sallei (Bivalvia: Dreissenacea), introduced into Hong Kong. J. Zool. 1989, 219, 469-485. [CrossRef]

51. Wang, J.; Huang, Z.; Zheng, C.; Lin, N. Population dynamics and structure of alien species Mytilopsis sallei in Fujian, China. J. Oceanogr. Taiwan Strait 1999, 18, 372-377. (In Chinese)

52. Cai, L.Z.; Hwang, J.S.; Dahms, H.U.; Fu, S.J.; Zhuo, Y.; Guo, T. Effect of the invasive bivalve Mytilopsis sallei on the macrofaunal fouling community and the environment of Yundang Lagoon, Xiamen, China. Hydrobiologia 2014, 741, 101-111. [CrossRef]

53. Song, J.-W.; Dong, Y.-H.; Li, H.T.; Zhao, Y. Invasive shellfish and their impacts on Chinese coastal waters. J. Biosaf. 2015, 24, 177-183. (In Chinese)

54. Zheng, F.Z.; Lu, C.Y.; Zhang, Y.K.; Zeng, Q.F. Study on the ecological engineering of mangrove landscape in Yundang Lagoon. In Yundang: From a Harbor to a Lagoon; Lu, C.Y., Ed.; Xiamen University Press: Xiamen, China, 2003; pp. 174-179. (In Chinese)

55. Guy-Haim, T.; Lyons, D.A.; Kotta, J.; Ojaveer, H.; Queirós, A.M.; Chatzinikolaou, E.; Orav-Kotta, H.; Magni, P.; Blight, A.J.; Como, S.; et al. Diverse effects of invasive ecosystem engineers on marine biodiversity and ecosystem functions: A global review and meta-analysis. Glob. Chang. Biol. 2018, 24, 906-924. [CrossRef]

56. The IUCN Red List of Threatened Species. Available online: www.iucnredlist.org (accessed on 15 August 2019).

57. Lutzen, J.; Jespersen, A.; Takahashi, T.; Kai, T. Morphology, structure of dimorphic sperm, and reproduction in the hermaphroditic commensal bivalve Pseudopythina Tsurumaru. J. Morphol. 2004, 262, 407-420. [CrossRef] [PubMed]

58. Magni, P.; Micheletti, S.; Casu, D.; Floris, A.; De Falco, G.; Castelli, A. Macrofaunal community structure and distribution in a muddy coastal lagoon. Chem. Ecol. 2004, 20, S397-S407. [CrossRef]

59. Nonnis Marzano, C.; Baldacconi, R.; Fianchini, A.; Gravina, M.F.; Corriero, G. Settlement seasonality and temporal changes in hard substrate macrozoobenthic communities of Lesina Lagoon (Apulia, Southern Adriatic Sea). Chem. Ecol. 2007, 23, 479-491. [CrossRef]

60. Cardone, F.; Corriero, G.; Fianchini, A.; Gravina, M.F.; Nonnis Marzano, C. Biodiversity of transitional waters: Species composition and comparative analysis of hard bottom communities from the south-eastern Italian coast. J. Mar. Biol. Assoc. UK 2014, 94, 25-34. [CrossRef]

61. Gravina, M.F.; Cardone, F.; Bonifazi, A.; Bertrandino, M.S.; Chimienti, G.; Longo, C.; Nonnis Marzano, C.; Moretti, M.; Lisco, S.; Moretti, V.; et al. Sabellaria spinulosa (Polychaeta, Annelida) reefs in the Mediterranean Sea: Habitat mapping, dynamics and associated fauna for conservation management. Estuar. Coast. Shelf Sci. 2018, 200, 248-257. [CrossRef]

62. Ingrosso, G.; Abbiati, M.; Badalamenti, F.; Bavestrello, G.; Belmonte, G.; Cannas, R.; Benedetti-Cecchi, L.; Bertolino, M.; Cerrano, C.; Chemello, R.; et al. Mediterranean Bioconstructions Along the Italian Coast. Adv. Mar. Biol. 2018, 79, 63-134.

(C) 2019 by the authors. Licensee MDPI, Basel, Switzerland. This article is an open access article distributed under the terms and conditions of the Creative Commons Attribution (CC BY) license (http://creativecommons.org/licenses/by/4.0/). 